\title{
Seniority and Business Mergers: The Union's Duty of Fair Representation
}

The union's duty of fair representation was seen by last term's Supreme Court as a "bulwark" in protecting individual workers from arbitrary union conduct. ${ }^{1}$ The importance of this protection to workers faced with a business merger or an intra-company transfer was illustrated in a recent District of Columbia Circuit Court of Appeals case, Truck Drivers Local 568 v. $N L R B,{ }^{2}$ concerning the integration of seniority lists following a merger of two trucking firms. There, the court affirmed a National Labor Relations Board decision, ${ }^{3}$ finding a violation of this duty when a union promised in a representation election that it would favor its members over the employees of the acquired firm.

On the surface, the decision not only reiterated the Supreme Court's faith in the duty of fair representation, but also represented a departure from a policy of judicial restraint. ${ }^{4}$ A closer look reveals, however, that instead of strengthening an individual's protection against the union's bad faith, ${ }^{5}$ the decision merely underscored how feeble that protection is. Essentially, the court of appeals' finding of a breach of the union's duty of fair representation was a response to the blatant display of bad faith on the part of the union. ${ }^{6}$ Where bad faith has not been so

1 Vaca v. Sipes, 386 U.S. 171, 182 (1967).

2379 F.2d 137 (D.C. Cir. 1967).

3 Red Ball Motor Freight, Inc., 157 N.L.R.B. 1237 (1966).

4 Most courts, when confronted with a charge of unfair representation regarding the merging of seniority lists, have chosen a course of non-intervention. "In deciding whether a change in seniority arrangements involves fundamental unfairness, the courts have allowed wide latitude for the give-and-take of collective bargaining and majority rule." Cox, The Duty of Fair Representation, 2 VIIL. L. REv. 151, 161 (1957). See Kahn, Seniority Problems in Business Mergers, 8 IND. \& LAB. REL. REv. 361, 364 (1955). But see Blumrosen, Union-Management Agreements Which Harm Others, 10 J. PUB. L. 345, 368-72 (1961).

In sharp contrast to the non-interventionist attitude of the courts is the active participation of federal agencies in insuring that minority groups are protected in merger situations. See Kent v. CAB, 204 F.2d 263 (2d Cir. 1953); Brown, Employee Protection and the Regulation of Public Utilities: Mergers, Consolidations, and Abandonment of Facilities in the Transportation Industry, 63 YArE L.J. 445 (1954); Kahn, supra note 4, at 365-71.

5 The term "bad faith" will be used often throughout this comment to indicate the intent of a union to discriminate against a group of employees. As will be shown, the courts, in litigation over merged seniority lists, have looked for bad faith only in the union's conduct in reaching a solution, avoiding scrutiny of the solution itself. Examination of some of these solutions will reveal discrimination fully as egregious as that found in Truck Drivers Local 568.

- See notes 68-77 and accompanying text infra. 
blatant, or where courts have followed a non-interventionist policy to extremes, the duty of fair representation has proved a meaningless safeguard to workers denied their seniority because of a union's political decision following a business merger.

It is not difficult to see that business mergers ${ }^{7}$ cause serious internal problems for the union. As the bargaining agent for these formerly separate groups of employees, ${ }^{8}$ the union will be faced with one of two situations. Either the job pool available will be diminished and thus jobs lost, or the formerly distinct sets of employees will now simply be under the same roof. In the first instance, the union must decide which of the employees of the two firms or departments will get the remaining jobs; in the second, it must resolve how seniority ${ }^{9}$ will be structured for the previously distinct groups.

Resolution of these problems can be determined in advance by the collective bargaining agreement. ${ }^{10}$ Generally, however, the employer allows the union to determine the new seniority structure as it sees fit. ${ }^{11}$ While at one time leaving such a matter in the hands of the union was

7 Mergers here refer to any form of amalgamation in which the entire assets of one firm are joined with that of another, or where entire departments of the same firm are joined together. A partial sale of assets is not considered a merger.

8 For the purposes of this comment, it will be assumed that the union is now the bargaining agent for two or more groups of unionized employees, either through an NLRB representation election as provided in the National Labor Relations Act § 9, 29 U.S.C. $\S 159$ (1964), or that the same union was the bargaining agent for the employees previously. For seniority rights in merging union and non-union employees, see NLRB $v$. Whiting Milk Corp., 342 F.2d 8 (1st Cir. 1965). For a general and occasionally helpful overview of the problem, see Note, Seniority Rights in Mergers, 52 Iowa L. Rev. 95 (1966).

9 "Seniority" here will refer to competitive status seniority-layoff, hire, promotion-as opposed to benefit seniority, which is concerned with employee fringe benefits and is usually calculated by length of service. For a general discussion of seniority, see S. SLICHTER, J. Healy \& E. Livernash, The Impact of Collegtive Bargatning on Management 104-41 (1960); Aaron, Reflections on the Legal Nature and Enforceability of Seniority Rights, 75 HARv. L. REv. 1535 (1962); Blumrosen, Seniority Rights and Industrial Change: Zdanok $v$. Glidden Co., 47 MINN. L. REv. 505 (1963); Kennedy, Merging Seniority Lists, LAB. ARB. \& IND. Change 1 (1963) (Proceedings of the Sixteenth Annual Mieeting of the National Academy of Arbitrators); Mater \& Mangum, The Integration of Seniority Lists in Transportation Mergers, 16 IND. \& LAB. REL. REv. 343 (1963); Sayles, Seniority: An Internal Union Problem, 32 HARV. Bus. Rev. 55 (1952).

102 BNA Collective Bargaining-Negotiations and Contracts 201 (1964); U.S. BUREAU of Labor Statistics, Dep't of Labor, Bull. Nos. 908-11; Collectrve Bargaining Provistons: SENIORITY 47-50 (1949). Union constitutions are another source of solutions to these problems. See SLICHTER, HEALY \& LIVERNASH, supra note 9, at 131; Kahn, supra note 4, at 372; Mater \&. Mangum, supra note 9, at 345-54. The duty of fair representation applies with equal force in those cases where the merger of seniority lists has been settled in advance by union constitution or by contract.

11 "Seldom does the company raise any serious obstacles, except to make known its concern for employee equities and its desire to retain experienced workers." SUrCHTER, HeAry \& LIVERNASH, supra note 9, at 131. See Kahn, supra note 4, at 362; Mater \& Mangum, supra note 9, at 349-44; Sayles, supra note 9, at 55. 
arguably an unfair labor practice, ${ }^{12}$ it seems clear that such is no longer the case. ${ }^{13}$

In making its determination, the union is confronted on the one hand with the majority which has the political power, ${ }^{14}$ and on the other by its duty to represent the minority interest fairly. ${ }^{15}$ It is this tension between majority rule and minority interests that is central to the problem of merging seniority lists. The courts' policy of nonintervention has done little to discourage the unions' general response of squeezing the minority ${ }^{16}$ and ignoring the ideal of fair representation. ${ }^{17}$

This comment will examine how the courts have resolved this tension and try to establish guidelines through which the duty of fair representation, as applied to mergers and intra-company transfers, could be strengthened instead of frustrated.

\section{The Framework of Non-Intervention}

Seniority rights are not inherent or vested, ${ }^{18}$ but are created by contract $^{19}$ or occasionally by statute..$^{20}$ As contractual rights, they may be

12 Pacific Intermountain Express Co., 107 N.L.R.B. 837, aff'd sub nom. Teamsters Local 41 v. NLRB, 225 F.2d 343 (8th Cir. 1955).

13 Teamsters Local 357 v. NLRB, 365 U.S. 667 (1961). Although this case refers specifically to the union hiring hall, the same would be true about seniority, i.e., the union's control of the determination of seniority rosters is not a per se unfair labor practice. It would be an unfair labor practice only if the union's control leads to discrimination.

14 The importance of having the majority power in determining seniority is well illustrated by Sayles, supra note 9, at 57-60, and by Kennedy, supra note 9, at 40-41. That employees will vote in their self interest is recognized in O'Donnell v. Pabst Brewing Co., 12 Wis. 2d 491, 107 N.W.2d 484, 489 (1961), and In re City of Green Bay, 44 Lab. Arb. 311, 316 (1965) (Anderson, Arbitrator).

15 The duty of fair representation first arose under the Railway Labor Act in Steele v. Louisville \& N.R.R., 323 U.S. 192 (1944). That case involved racial discrimination by a union in eliminating Negroes from certain railroad jobs. See Vaca v. Sipes, 386 U.S. 171 (1967); Humphrey v. Moore, 375 U.S. 335 (1964); Syres v. Oil Workers Local 23, 350 U.S. 892 (1955); Ford Motor Co. v. Huffman, 345 U.S. 330 (1953).

16 For instance, note the history of the Gulf-Sohio merger in Kennedy, supra note 9, at 40-41, or the history of the Pan American and American Overseas Airlines merger in Kahn, supra note 4, at 368-71.

17 Exclusive bargaining agents may not "make agreements more favorable to the majority than to the minority." Radio Officers' Union v. NLRB, 347 U.S. 17, 47 (1954), citing S. REP. No. 573, 74th Cong., Ist Sess. 13 (1935).

18 See, e.g., Ford Motor Co. v. Huffman, 345 U.S. 330 (1953); Wagner Mfg., Inc. v. Culbertson, 59 L.R.R.M. 2599 (Ind. App. Ct. 1955). But cf. Zdanok v. Glidden, 288 F2d 99 (2d Cir.), cert. granted on other grounds, 368 U.S. 814 (1961). Glidden has come under heavy academic fire by Aaron, supra note 9, and others, and is distinctly a minority view. For a favorable review of the case see Blumrosen, supra note 9.

19 "Barring legislation not here involved, seniority rights derive their scope and significance from union contracts." Aeronautical Lodge 727 v. Campbell, 337 U.S. 521, 526 (1949). Colbert v. Brotherhood of R.R. Trainmen, 206 F.2d 9, 13 (9th Cir. 1953); Elder v. New York Cent. R.R., 152 F.2d 361, 364-65 (6th Cir. 1945).

20 Selective Training \&: Service Act of 1940, ch. 720, \& 8, 54 Stat. 890. 
altered by the union at any time.21 But although a union has the power to determine or modify seniority rights, it must represent all its members fairly.22 Determinations by the union which are arbitrary, in bad faith, ${ }^{23}$ unfair, irrelevant, invidious, ${ }^{24}$ political, ${ }^{25}$ or racial $^{26}$ are violations of the duty of fair representation. Whether such conduct is an unfair labor practice is as yet unsettled. ${ }^{27}$ Employees would appear, however, to have recourse to either the NLRB $^{28}$ or the courts ${ }^{29}$ to enforce this duty.

But while espousing a duty of fair representation and explaining its content, courts have allowed unions "a wide range of reasonableness" 30 in structuring merged seniority lists. Reasonableness, as interpreted

21 See O'Donnell v. Pabst Brewing Co., 12 Wis. 2d 491, 107 N.W.2d 484, 487 (1961); Ford Motor Co. v. Huffman, 345 U.S. 330 (1953); Note, Seniority Rights in Mergers, 52 IOWA L. REV. 95 n.5 (1966).

22 See note 15 supra.

23 Vaca v. Sipes, 386 U.S. 171,177 (1967)

24 Miranda Fuel Co., 140 N.L.R.B. 181, 185 (1962), enforcement denied, 326 F.2d 172 (2d Cir. 1963). In United Rubber Workers Local 12 v. NLRB, 368 F.2d 12 (5th Cir. 1966), the Miranda Fuel Co. doctrine-that a breach of its duty of fair representation was a union unfair labor practice-was upheld.

25 Radio Officers Union v. NLRB, 347 U.S. 17, 47 (1954); Ferro v. Railway Express Agency, Inc., 296 F.2d 847, 851 (2d Cir. 1961); Mount v. International Bhd. of Locomotive Engineers, 226 F.2d 604, 607 (6th Cir. 1955). Discrimination based on union membership is also prohibited. Wallace Corp. v. NLRB, 323 U.S. 248 (1944); NLRB v. Machinists Lodge 727, 279 F.2d 761 (9th Cir. 1960).

20 Steele v. Louisville \& N.R.R., 323 U.S. 192 (1944); Tunstall v. Brotherhood of Locomotive Firemen, 323 U.S. 210 (1944).

27 Compare NLRB v. Miranda Fuel Co., 326 F.2d 172 (2d Cir. 1963), with Local 12, United Rubber Workers Local 12 v. NLRB, 368 F.2d 12 (5th Cir. 1966). In Vaca v. Sipes, 386 U.S. 171 (1967), the issue as to whether or not a violation of the duty of fair representation is an unfair labor practice was the crucial difference that separated the majority and concurring opinions. Justices Fortas and Harlan and Mr. Chief Justice Warren said specifically that a union that breached its duty of fair representation committed an unfair labor practice, 386 U.S. at 198, as did Justice Goldberg in Humphrey v. Moore, 375 U.S. 335, 351 (concurring). In both these opinions, the majority "assumed" such conduct to be an unfair labor practice. For an excellent discussion of the issues in Vaca $v$. Sipes, see Lewis, Fair Representation in Grievance Administration: Vaca v. Sipes, 1967 Sup. CT. REv. 81.

28 Miranda Fuel Co., 140 N.L.R.B. 181 (1962).

29 See Labor-Management Relations Act (Taft-Hartley Act) § 301, 29 U.S.C. § 185 (1964); Humphrey v. Moore, 375 U.S. 335 (1964). Under the Railway Labor Act, a fair representation suit does not come under the jurisdiction of the Adjustment Board, but can be brought into federal district court. Conley v. Gibson, 355 U.S. 41,45 (1957).

30 Ford Motor Co. v. Huffman, 345 U.S. 330, 338 (1953). The controversy here arose over a seniority provision in the collective bargaining contract giving veterans credit for pre-employment military service. The Court upheld the provision and, in so doing, allowed unions broad power at the bargaining table: "Inevitably differences arise in the manner and degree to which the terms of any negotiated agreement affect individual employees and classes of employees. The mere existence of such differences does not make them invalid. The complete satisfaction of all who are represented is hardly to be expected. A wide range of reasonableness must be allowed a statutory bargaining representative in serving the unit it represents, subject always to complete good faith and honesty of 
by courts and arbitrators, has included dovetailing, ${ }^{31}$ endtailing ${ }^{32}$ and countless other intricate formulas. ${ }^{33}$ This "wide range of reasonableness" has provided the union with great discretion in two ways: first, courts will assume compliance with the duty of fair representation unless a bad faith motive or hostility can be shown, ${ }^{34}$ and second, courts have at times used this "wide range of reasonableness" language so broadly as to negate any requirement of fair representation. ${ }^{35}$

In effect, courts will not look at the substance of the union's determination until the plaintiff proves that the union has exhibited bad faith. In the area of racial discrimination, the group discriminated against is very visible and courts have little trouble in finding a union's breach. ${ }^{36}$ In a nonracial context, however, the group is less visible and proof of discrimination more difficult. ${ }^{37}$

purpose in the exercise of its discretion." $I d$. at 338. The powers extended to the union at the bargaining table in Ford are also accorded it in the administration of the agreement. Vaca v. Sipes, 386 U.S. 171 (1967). See Humphrey v. Moore, 375 U.S. at 351, 353-55 (Goldberg, J., concurring).

31 "Dovetailing" means to merge seniority lists using date of original hire with either of the companies that are party to the merger. See Humphrey v. Moore and cases cited at 375 U.S. 335, 347 n.10 (1964); Pratt v. Wilson Trucking Co., 214 Ga. 385, 104 S.E.2d 915 (1958); In re City of Green Bay, 44 Lab. Arb. 311 (1965); O'Donnell v. Pabst Brewing Co., 12 Wis. 2d 491, 107 N.W.2d 484 (1961).

32 "Endtailing" means placing one group of employees at the bottom of the seniority list of another group. See Bieski v. Eastern Auto Forwarding Co., 231 F. Supp. 710 (D. Del. 1964), aff'd, 354 F.2d 414 (3d Gir. 1965); Zeaner v. Truck Drivers Local 107, 234 F. Supp. 901 (E.D. Pa. 1964); Administrative Rulings of the NLRB General Counsel, 47 L.R.R.M. 1527 (1961) (Case No. SR-1114). But see Kahn, supra note 4, at 373: "To place all of the employees from one list below those on the other list . . . is really to reject integration."

33 In re Pan American World Airways, 19 Lab. Arb. 14 (1952) (Cole, Arbitrator) (twothirds weight to length of service, one-third weight to rank on original seniority list); Kahn, supra note 4, at 373-78 (integration on basis of "distance" from first place on either list; integration emphasizing status of employee in his former company); Kennedy, supra note 9, at 5-34 (surviving group principle, absolute rank, follow-the-work); Mater \& Mangum, supra note 9 , at 345-63.

34 "[C]ourts, unable to find standards by which to test the fairness of economic distinctions in collective agreements, apply a heavy presumption of legality to union action." Wellington, Union Democracy and Fair Representation: Federal Responsibility in a Federal System, 67 YALE L.J. 1327, 1357 (1958). See Hardcastle v. Western Greyhound Lines, 303 F.2d 182, 185-86 (9th Cir. 1962); Cunningham v. Erie R.R., 266 F.2d 411, 417 (2d Cir. 1959); Colbert v. Brotherhood of R.R. Trainmen, 206 F.2d 9, 13 (9th Cir. 1953); Pratt v. Wilson Trucking Co., 214 Ga. 385, 104 S.E.2d 915, 916 (1958); Wagner Mfg. Co. v. Culbertson, 59 L.R.R.M. 2599, 2603 (Ind. App. Ct. 1965); Markham v. American Motors Corp., 55 L.R.R.M. 2757, 2760 (Wis. Sup. Ct. 1964); O'Donnell v. Pabst Brewing Co., 12 Wis. 2d 491, 107 N.W.2d 484, 490 (1961); Administrative Rulings of the NLRB General Counsel, 47 L.R.R.M. 1527 (1961) (Case No. SR-1114).

35 See NLRB v. Wheland Co., 271 F.2d 122 (6th Gir. 1959); notes 49-58 and accompanying text infra.

36 See note 15 supra. Since the duty of fair representation first arose in a racial context, some courts regarded only racial discrimination as being prohibited. Napier v. System Fed'n No. 91, 127 F. Supp. 874, 892 (W.D. Ky. 1955): "In the absence of racial discrimination, no case has been cited ... where a court has upset an agreement because of chal- 
Even where discrimination is evident, courts may choose not to upset the merged lists. Perhaps the most infamous litigation illustrating judicial non-intervention in seniority matters grew out of the absorption by the Trailmobile Company of its wholly owned subsidiary, Highland Body Manufacturing Company. ${ }^{38}$ The employees of both companies were represented by the UAW-AFL and were covered by the same contract. ${ }^{39}$ The consolidation caused a dispute over seniority rights in which the Trailmobile employees, who outnumbered the Highland workers by ten to one, had sought to endtail the Highland group. ${ }^{40}$ By consent of both groups, the dispute was certified to the International Executive Board of the union for adjudication.41 The union ruled that the once separate lists should be dovetailed. The Trailmobile workers rejected this solution and called for a new representation election in which CIO affiliation was voted by the disgruntled majority. A new contract was negotiated endtailing the Highland employees and a series of suits attacking the agreement ensued.

The basic issue of fair representation, however, was not met squarely until six years after the first of these suits was brought. ${ }^{42}$ In Britt v. Trail-

lenged changes in seniority provisions." This view, of course, is erroneous. See generally Sovern, The National Labor Relations Act and Racial Discrimination, 62 CoLuM. L. REv. 563 (1962); Winter, Improving the Economic Status of Negroes Through Laws Against Discrimination: A Reply to Professor Sovern, 34 U. CHr. L. Rev. 817 (1967); Comment, Racial Discrimination and the Duty of Fair Representation, 65 CoLuM. L. REv. 273 (1965). Title VII of the Civil Rights Act of 1964, 42 U.S.C. $\$ 2000-\mathrm{h}(6)$, strengthens the courts' hand in preventing racial discrimination by labor unions. See Quarles v. Philip Morris, Inc., 67 L.R.R.M. 2098 (E.D. Va. 1968); Comment, Title VII, Seniority Discrimination and the Incumbent Negro, 80 HARv. L. REv. 1260 (1967).

37 Courts are apt to invoke the language of Ford Motor Co. v. Huffman, 345 U.S. 330 (1953). See, e.g., Hardcastle v. Western Greyhound Lines, 303 F.2d 182, 187 (9th Cir. 1962): "That portions of an electorate will be dissatisfied with the result of an election is a fact inherent in the democratic process and the principle of majority rule." This sort of reasoning makes employees charging unfair representation unattractive plaintiffs.

38 Trailmobile Co. v. Whirls, 331 U.S. 40 (1947); Britt v. Trailmobile Co., 179 F.2d 569 (6th Cir. 1950); Hess v. Trailer Co. of America, 31 Ohio Op. 566 (C.P. 1944); The Trailer Co. of America, 51 N.L.R.B. 1106, 53 N.L.R.B. 1248 (1943).

39 The Trailer Co. of America, 51 N.L.R.B. 1106, 1113 (1943).

40 Cox, supra note 4 , at 162.

4151 N.L.R.B. at 1110.

42 The first suit, Hess v. Trailer Co. of America, 31 Ohio Op. 566 (C.P. 1944), pre-dated Steele v. Louisville is N. R.R., and so the issue of fair representation was not presented. In a later suit brought by a member of the Highland unit under section $8(c)$ of the Selective Training \& Service Act of 1940, 54 Stat. 885, 890, providing that a veteran "shall be so restored [to his job] without loss of seniority," the Supreme Court avoided the question of unlawful discrimination by saying that it was not properly raised. Trailmobile Co. v. Whirls, 331 U.S. 40, 50 (1947). Justices Frankfurter and Jackson dissented: "The record indicates that [plaintiff's seniority rights] have never been terminated or modified by good faith collective bargaining in the interests of the craft. It raises the suspicion that they were simply misappropriated to the benefit of the majority group which was under a duty to represent his interests as well as its own." Id. at 69. 
mobile Co., ${ }^{43}$ the Sixth Circuit held: "Whatever we might think of the fairness of the differentiation, the discrimination was in pursuance of the bargaining process and not without some basis, forestalled a strike and was therefore not invalid." 44

The result in Trailmobile has been criticized severely and often.45 Given the antagonism between the two groups, ${ }^{46}$ the courts should have required, at the very least, some showing of the reasonableness of the union's decision. ${ }^{47}$ The most, perhaps, that can be said for the Sixth Circuit's decision is that, on policy grounds, the court chose industrial peace over individual rights. ${ }^{48}$ This is, however, a false choice, for the dilemma is to maintain industrial peace while representing the minority interest fairly. Industrial peace, i.e., appeasing the majority, can always be bought at the expense of the minority interest. The duty of fair representation presupposes a reconciliation of the two, rather than a choice. If the courts permit a union to destroy a minority's interest on the grounds that "it forestalled a strike," the duty of fair representation has been reduced to nothing more than rhetoric.

The Sixth Circuit was again faced with the problem of merged seniority lists in NLRB v. Wheland Co.99 There, the company decided to consolidate its manufacturing division-consisting of a production and maintenance unit of about 135 workers represented by the Machinists, and a residual unit of about 25 represented by the Steelworkers-with its ordnance division of 212 represented by the Allied Industrial Workers. The consolidation was prompted by the curtailing of the ordnance operations.

Allied submitted 206 newly signed authorization cards, solicited exclusively from the former ordnance employees, and was recognized by Wheland as the bargaining representative for the new consolidated operation. Wheland and Allied entered into an interim agreement providing that manufacturing division employees could be moved to the consolidated plant, but that employees so moved would not replace ordnance employees. Later, the two established a seniority list under which employees formerly part of the manufacturing division would be given credit for one year's seniority for each 2.6623 years actually

\footnotetext{
$43 \quad 179$ F.2d 569 (6th Cir. 1950).

44179 F.2d at 573 .

45 Cox, supra note 4, at 163; Wellington, supra note 34, at 1357; Comment, Duty of Union to Minority Groups in the Bargaining Unit, 65 HARv. L. Rev. 490, 499 (1952).

4651 N.L.R.B. 1114.

47 Cox, supra note 4 , at 163, makes a strong argument for endtailing under certain circumstances.

48 See notes 78-80 and accompanying text infra.

49271 F.2d 122 (6th Cir. 1959).
} 
worked in the old division, while employees formerly with the ordnance division would receive full credit for their past service. Overall employment was reduced from 375 to a little over 300 .

The NLRB found that Wheland violated sections $8(a)(1)$ and (2) of the National Labor Relations Act ${ }^{50}$ by granting preferential seniority to former ordnance employees on the basis of their membership and past representation by Allied. ${ }^{51}$ By implication, the Board also found that Allied had violated its duty of fair representation to the former manufacturing employees. ${ }^{52}$

The Sixth Circuit reversed. ${ }^{53}$ The court concluded that the solution to the seniority problem would "inevitably be unsatisfactory to some employees" but in the light of Trailmobile Co. v. Whirls ${ }^{54}$ and Ford Motor Co. v. Huffman"55 the decision "was not an invalid exercise of the power conferred upon the respective negotiating parties."56

To say that the seniority roster would "inevitably be unsatisfactory to some employees" was merely to state the obvious. ${ }^{57}$ The question, however, is which employees are to find the solution "unsatisfactory"? What should be the criteria? Here, the court recognized neither the tension nor its resolution. The solution for the union was simplethose who supported and belonged to Allied were given job preference. It was nothing more than the majority exerting its strength over the minority. Apart from the solution, however, the union exhibited no manifestations of bad faith. The court here looked at form, disregarded substance, and approved a scheme that was discriminatory

50 Sections 8(a)(1) and (2) refer to an employer interfering with the employees' rights of self organization and their collective bargaining rights and to an employer attempt to dominate or support a union.

51 The Wheland Co., 120 N.L.R.B. 814, 818 (1958).

52120 N.L.R.B. at 819 n.7. Wheland seemed to anticipate the Board's Miranda Fuel Co. holding. While specifically finding the employer guilty of an $8(a)(1)$ violation in Wheland, the Board laid the groundwork for Miranda Fuel Co., which held that: "To the extent ... that an employer participates in such union's arbitrary action against an employee, the employer himself violates section 8(a)(I) of the Act." 140 N.L.R.B. at 185-86. In Red Ball Motor Freight, Inc., 157 N.L.R.B. 1237, 1245 (1966), the Board saw Wheland as a fair representation case.

53 The Wheland Co. v. NLRB, 271 F.2d 122 (6th Cir. 1959).

54 "An employee has 'no inherent right to seniority in service." 331 U.S. 40, 53 n.21 (1947).

55 "The complete satisfaction of all who are represented is hardly to be expected. . . . Compromises on a temporary basis, with a view to long-range advantages, are natural incidents of negotiation." 345 U.S. 330, 338 (1953).

50 271 F.2d at 125.

57 Other such perceptive statements include one by the Pennsylvania Supreme Court in Brotherhood of R.R. \& S.S. Clerks v. Girard Lodge 100, 384 Pa. 248, 259, 120 A.2d 523, 528 (1956): "When there are only five apples for six people, it is impossible for each person to receive a whole apple." 
on its face and for which no other "reasonable" explanations were advanced. ${ }^{58}$

In Humphrey v. Moore, ${ }^{59}$ E\&L Transport Company's Louisville business had been absorbed by Dealers Transport Company. Both groups of employees were represented by the same Teamsters local. When layoffs began at E\&L, three E\&L employees filed grievances claiming that the seniority lists should be dovetailed. The national joint committee, after urging by the local president, supported dovetailing, and since E\&L's employees had generally greater seniority than those at Dealers, the result was a large-scale layoff of Dealers employees. ${ }^{60}$

Several of the aggrieved Dealers employees brought a class suit in state court alleging unfair representation. The case ultimately reached the Supreme Court, where the dovetailed list was held valid.

The Court found that dovetailing "is a familiar and frequently equitable solution to the inevitably conflicting interests which arise in the wake of a merger or an absorption such as occurred here." 61 Further, it discovered "no substantial evidence of fraud, deceitful action or dishonest conduct." 62 In sum, the Court found that the union had "acted upon wholly relevant considerations" and "in good faith and without hostility or arbitrary discrimination."63

The difficulty with Humphrey v. Moore is two-fold. First, though noting the fairness of dovetailing generally, the Court never explained or analyzed why this method was substantively equitable, given the particular facts of the case. ${ }^{64}$ Second, the Court didn't inquire into the

58 The Wheland Co., 120 N.L.R.B. 814, 819 (1958). Even allowing for a "wide range of reasonableness" for the union here, it should be noted how closely the Court in Ford Motor Co. analyzed the policy of granting veterans additional seniority in contrast to the total lack of discussion in Wheland as to why ordnance employees should get any preference.

59375 U.S. 335 (1964).

60 Moore v. Teamsters Local 89, 356 S.W.2d 241, 244 (Ky. Ct. App. 1962). Out of the first 200 men hired, only 58 had worked for Dealers. This meant that 96 Dealers employees were laid off.

61375 U.S. at 347.

62 Id. at 348 .

63 Id. at 350 .

64 Analysis of the merits of dovetailing of the sort undertaken in In re City of Green Bay, 44 Lab. Arb. 311 (1965), was notably absent in the opinion. In addition, Mr. Justice White, 375 U.S. at 347 n.10, quoted Kahn out of context. The full quote should read: "Work opportunities should be allocated between the two employee groups in proportion to the contribution made to the joint operation by their respective original employers. Integration of seniority lists should ordinarily be accomplished on the basis of each employee's length of service with his original employer . ..." Kahn, Seniority Problems in Business Mergers, 8 IND. \& LAB. REL. Rev. 361, 378 (1955). Mr. Justice White cited only the last sentence to support dovetailing. What Kahn, in fact, had in mind was a two-step procedure: first, divide the remaining jobs between the two groups of employees in proportion to job opportunities created by each of their respective em- 
motives of the union in choosing dovetailing. Why did the union favor dovetailing? Did E\&L's employees want dovetailing because it was an "equitable solution" or because it gave them more jobs? In fact, in this merger the union could probably have chosen any number of solutions with equal impunity. ${ }^{65}$

The key to the Court's opinion is, however, that since the union exhibited no bad faith, it became unnecessary to grapple with the equities of dovetailing. ${ }^{66}$ Whether the union here exhibited bad faith is an arguable matter, ${ }^{67}$ but as in Wheland, scant attention was paid to the solution, the Court instead concerning itself with form.

Truck Drivers Local 568 v. NLRB ${ }^{68}$ would appear, on its face, to strengthen the duty of fair representation. The case arose when Red Ball Motor Freight, Inc., with fifty employees represented by the Union of Transportation Employees (UTE), acquired another trucking firm in Shreveport, Louisiana, with about thirty workers represented by the Teamsters. The company decided to combine the two groups of workers in one terminal and reached an agreement with the two unions that it would initiate representation proceedings to determine which of the two would become the exclusive bargaining agent. During the campaign, the UTE represented that it would never agree to dovetailing

ployers; second, with the employees now selected to fill the remaining jobs, integrate the seniority lists, using the date of original hire. For a full discussion of this issue, see notes 96-109 and accompanying text infra.

65 See notes 31-33 supra. Bieski v. Eastern Automobile Forwarding Co., 231 F. Supp. 710 (D. Del. 1964), provides an interesting contrast in a similar fact situation. Two companies delivered Chrysler cars to an allocated area, but because of competition from the railroads, one was unable to make a profit and sold out to the other. The local president suggested that the seniority lists be dovetailed, but the employees of the absorbing company rejected this solution. At the joint employer-employee committee, a decision was reached that the absorbed company's employees had no contractual rights to claim seniority with the absorbing company, and the absorbed employees were endtailed. That decision was upheld by the district court and affirmed by the Third Circuit. 354 F.2d 414 (3d Cir. 1965).

66 In Vaca v. Sipes, 386 U.S. 171, 190 (1967), the Court said: "A breach of the statutory duty of fair representation occurs only when a union's conduct toward a member of the collective bargaining unit is arbitrary, discriminatory, or in bad faith. See Humphrey v. Moore ...." Thus, without a showing of bad faith, the Court will not review the reasonableness of the decision.

67 See R. \& E. JAMes, Hoffa and the TeAmsters 167-185 (1965). This book gives a very thorough analysis of the grievance procedure used by the Teamsters in the central states, the same operating in Humphrey $v$. Moore. Because there is no arbitration as a final step in the grievance procedure, the Teamster agreement in the central states does not have a "no strike" clause. See Textile Workers v. Lincoln Mills, 353 U.S. 448 (1957). This gave Hoffa an opportunity to manipulate the grievance system so as to strengthen the Teamsters' power both in organizing and at the bargaining table. It is doubtful that any grievance settlement made under this procedure fulfilled the union's duty of fair representation.

68379 F.2d 137 (D.C. Cir. 1967). 
seniority lists and that UTE members' seniority would be protected against that of the Teamsters. Two elections were held, both won narrowly by the UTE and both set aside because of unfair labor charges against the union. ${ }^{69}$

The NLRB found that in threatening to take action against the Teamsters, if elected, upon "irrelevant, invidious or unfair" considerations, the UTE breached its duty of fair representation under section $8(\mathrm{~b})(\mathrm{I})(\mathrm{A}),{ }^{70}$ as enunciated in Miranda Fuel Co. ${ }^{71}$ Although the NLRB toyed with the question of substance, i.e., that dovetailing would be reasonable and endtailing not, it rested its finding of a violation on the "affirmative evidence to support the conclusion that the action which UTE proposed was in derogation of its obligation of fair representation."72 It rested its conclusion on the inference "that UTE's promise to seek preferential seniority for the UTE employees was based on its desire to assure [its election] and was not conscientiously adopted in an effort to find a workable solution to an admittedly difficult problem." 73

The District of Columbia Circuit affirmed, ${ }^{74}$ basing its decision, like the Board's, primarily on the bad faith conduct of the union. "It is not our function to prefer one [method of integration] as against any other," the court said. "But it seems clear ... that UTE has renounced any good faith effort to reconcile the interests of the [two groups]."75 The union's campaign against dovetailing was found to be based not on a consideration of the merits, ${ }^{76}$ but solely on its desire to get elected.

Because of the UTE's overt discrimination, the outcome in Truck Drivers Local 568 was not surprising. But the holding is a narrow one; in the absence of bad faith conduct, the UTE might very well have discriminated as it pleased. Had the UTE won the election, held open hearings, ponderously weighed the alternatives and then decided against dovetailing (which was what it was going to do all along), the court would probably not have intervened. ${ }^{77}$

69 Both the NLRB and the court of appeals found the employer violated sections 8(a)(1) and (2) of the National Labor Relations Act, 29 U.S.C. § 158(a)(1)-(2), but such findings are irrelevant to this comment.

70 Section $8(b)(1)(A)$ makes it a violation for the union to restrain or coerce employees in their right to self organization.

71 See note 24 supra.

72157 N.L.R.B. at 1245.

$73 \mathrm{Id}$.

74379 F.2d 137 (D.C. Cir. 1967).

$75 \mathrm{Id}$. at 143.

76 The court mentioned two arguments against dovetailing: first, the difficulty of the jobs performed in the new terminal; and second, that the absorbed firm was going out of business and, but for the merger, its employees would have lost their jobs. 379 F.2d at 142. Neither argument applies in this case.

77 See notes 32 \& 65 supra. 
All four decisions discussed above demonstrate the refusal of the courts to analyze the solutions which the various unions reached. None, with the possible exception of Truck Drivers Local 568, fully takes note of the tensions that underlie the situation. Only in Truck Drivers Local 568 is a violation found, and then not because the solution was substantively so extraordinary, but because the court viewed it as part of a scheme to discriminate against one set of employees. This leads to the conclusion that unless the union's bad faith conduct is blatant, as in Truck Drivers Local 568, the duty of fair representation puts very little restraint on the union. 'This conclusion is strengthened by the courts' emphasis on procedure rather than substance. In effect, this triumph of form over substance, coupled with a policy of non-intervention, keeps the courts on the periphery of the problem-how the union reached the solution-rather than at its center-the solution itself.

At the heart of this judicial attitude of non-intervention are three considerations. First, as a general rule, courts should be wary of entertaining suits by individuals challenging the appropriateness of union decisions at the bargaining table. For if every agreement were subject to the close scrutiny of the courts, the underpinnings, indeed the success, of a national labor policy of promoting settlement of industrial conflict by the parties concerned would be undermined. ${ }^{78}$ Underlying the broad powers accorded the union in Ford Motor Co. v. Huffman is the Court's assumption that peaceful and stable labor relations will be encouraged if the union has the power to bind its members when it reaches agreement with the employer through collective bargaining. Court decisions second-guessing the union or limiting its powers would disrupt this relationship. ${ }^{79}$ Thus, in Trailmobile, Wheland and Humphrey, the union is given a wide range of discretion to merge seniority lists. ${ }^{80}$

Instead of involving the interplay between union and management, however, the integration of seniority lists is generally considered by

78 "The collective bargaining system as encouraged by Congress and administered by the NLRB of necessity subordinates the interests of an individual employee to the collective interests of all employees in a bargaining unit." Vaca v. Sipes, 386 U.S. 171, 182 (1967).

79 The Court recognized this in Vaca $v$. Sipes when it ruled that arbitrariness or bad faith must be shown to void a union's decision to settle a grievance short of arbitration: "If the individual employee could compel arbitration of his grievance regardless of its merit, the settlement machinery provided by the contract would be substantially undermined, thus destroying the employer's confidence in the union's authority and returning the individual grievant to the vagaries of independent and unsystematic negotiation." Id. at 191.

80 Note particularly Mr. Justice Goldberg's concurring opinion in Humphrey v. Moore, 375 U.S. 335, 351 (1964), which would give the union and the employer a free hand in altering or modifying the contract. 
employers to be an internal union matter. ${ }^{81}$ And although courts have often considered internal union matters beyond their reach, it seems clear that when dealing with the duty of fair representation this is no longer so. ${ }^{82}$ Moreover, the solution to the problem of integrating seniority lists involves neither the temporary compromises looking toward long run advantages that Ford Motor $\mathrm{Co}^{83}$ talked about, nor the continuing problem of choosing among grievances to go to arbitration that was the crux of the matter in Vaca v. Sipes, ${ }^{84}$ but is generally resolved only once in a bargaining relationship. ${ }^{85}$ And while not interfering with the union-management relationship, closer judicial scrutiny of merged seniority lists would strengthen a policy of protection to individual workers articulated by courts, ${ }^{86}$ statutes, ${ }^{87}$ and commentators. ${ }^{88}$

A second related reason for judicial passivity is hesitance to interfere with the internal politics of a union. The union serves, in part, as a mediating agency, resolving the conflicting claims of its internal groups. The struggle between skilled and semi-skilled groups within a given local or international is an old story. ${ }^{89}$ In seniority matters, competing groups vie for a structure that might, for example, allow older workers

81 See Kahn, supra note 64 , at 362. See also note 11 supra.

82 " $[\mathrm{L}]$ abor . . u unions which may be chosen as bargaining agents are regarded as voluntary and not governmental in character, and not subject to judicial interference in their internal affairs so long as they fairly represent all of the employees within the class ....." Courant v. International Photographers of Motion Picture Industry Local 659, 176 F.2d 1000, 1003 (9th Cir. 1949), cert. denied, 338 U.S. 943 (1950).

It is also significant that there has been a change in mood in Congress, which originally saw labor relations as the conflict between union and management and the need for industrial peace. See Findings and Policies of the National Labor Relations Act, 29 U.S.C. $\S \S 141$ et seq. (1964). Recently, Congress has become concerned with individual members' rights and the need to protect the individual worker against his union. See Declarations of Findings, Purposes and Policy, Labor-Management Reporting and Disclosure Act of 1959, 73 Stat. 519 (Landrum-Griffin Act).

83 Ford Motor Co. v. Huffman, 345 U.S. 330, 338 (1953).

84386 U.S. 171, 190-93 (1967).

85 Cf. Belanger v. Amalgamated Motor Coach Employees Local 1128, 254 Wis. 344, 36 N.W.2d 414 (1949).

86 Vaca v. Sipes, 386 U.S. 171, 182 (1967), sees the duty of fair representation "as a bulwark to prevent arbitrary union conduct against individuals stripped of traditional forms of redress by the provisions of the federal labor law." See note 13 supra.

87 Section 101 of the Landrum-Griffin Act, 29 U.S.C. $\$ 411$ (1964), provides for a bill of rights for members of labor organizations. The duty of fair representation has been read into both the Railway Labor Act (Steele v. Louisville \& Nashville R.R., 323 U.S. 192 (1944)) and the National Labor Relations Act (Syres v. Oil Workers Local 23, 350 U.S. 892, rev'g mem., 223 F.2d 739 (1955)).

88 Blumrosen, The Worker and Three Phases of Unionism: Administrative and Judicial Control of the Worker-Union Relationship, 61 Mick. L. REv. 1435, 1464-1526 (1963); Cox, Rights Under a Labor Agreement, 69 HARv. L. REv. 601, 630-38 (1956); Hanslowe, Individual Rights in Collective Labor Relations, 45 CORNELL L.Q. 25, 43-55 (1959); WeIlington, supra note 34, at 1331-43.

s9 Sayles, Seniority: An Internal Union Problem, 32 Harv. Bus. Rev. 55 (1952). 
to avoid unpleasant tasks or give younger workers a better chance for promotion. ${ }^{90}$ Unions, as democratic institutions, must allow some leeway for the majority to have its way. Although political factors may operate in all seniority decisions, the merger situation appears to involve important differences in degree that warrant imposing external limits on such factors. As the discussed cases reveal, the relative political power of the two groups of workers in the merger setting usually becomes the sole, or at least, the dominant consideration in merging seniority lists. It is this use of raw political power, coupled with the importance of the decision-whether a substantial number of employees will keep their jobs-which, in the light of the duty of fair representation, far outweighs the court's reluctance to upset the union's political machinery.

The third consideration that has led to a policy of non-intervention is the inability of courts to fashion a standard to judge the substantive fairness of merged seniority lists. ${ }^{91}$ It was enough then in Trailmobile for the solution "to forestall a strike," 92 and in Humphrey for it to be "rational."03 In Truck Drivers Local 568, the court used no standard at all: "It is not our function," the court said, "to prefer one [method of integration] as against any other." 94 What is needed, then, is some test by which the courts could judge the substantive fairness of the union's decision without relying solely on a strict bad faith conduct test. Most important, this standard should be one that conforms to the economic rationale behind seniority, getting away from the present emphasis on political considerations. ${ }^{95}$ It is to such a standard we now turn.

\section{A Theory of SENIORITY}

Seniority rights depend upon an employer-employee relationship; they do not guarantee such a relationship but merely define the rights of an employee when that status is in existence. ${ }^{96}$ These rights, under competitive status seniority, concern preference for jobs. And being contractual, this preference is defined by the bounds of the collective

90 See id. at 55-61.

91 "What is clear is that courts have not found it easy to devise standards which are institutionally sound in this esoteric world of collective bargaining. More often than not, this difficulty has been recognized and has tended to restrain judicial intervention." Wellington, supra note 84 , at 1341 .

92 179 F.2d 569, 572 (6th Cir. 1950).

93375 U.S. 335, 347 (1964).

24 379 F.2d 137, 142 (D.C. Cir. 1967).

85 A solution calling for mandatory dovetailing, for example, would completely remove any political considerations by a union, but would be incompatible with an understanding of the concept of seniority. See notes 103-105 and accompanying text supra.

96 IAM Local 2040 v. Servel, Inc., 268 F.2d 692, 698 (7th Cir.), cert. denied, 861 U.S. 884 (1959). 
bargaining agreement. The importance of seniority is the ability of one worker in the seniority unit to claim a job over another within that same group. Absolute lengths of time are only relevant in reference to the relative number of years other workers within the same group have. ${ }^{97}$ To say that a worker has twenty years' seniority is meaningless until it is known whether this is more or less than everyone else in his group. Moreover, to acquire this seniority in a particular unit, individual workers may have, among other things, taken lower wages, ${ }^{98}$ given up labor force mobility, ${ }^{99}$ or refrained from punching a supervisor in the nose. ${ }^{100}$

Seniority not only governs the competition for jobs within the unit, but also acts as a buffer against workers outside the unit. What happens if an employee of $\mathrm{B}$, who has worked in a similar industry for more years than half of A's employees, is laid off and now applies for a job at $A$ ? He says that he should get a job at $A$ since he has more seniority than half of A's employees. But he doesn't because he has not acquired seniority at Company $\mathrm{A}$; he has done nothing to give him a preference to job rights or opportunities at $A$.

Suppose that, because of increased competition from the railroads, trucking firm A with 100 workers on 100 routes merges with trucking firm B with 200 workers and 200 routes. ${ }^{101}$ The merged firm will have only 200 routes -75 from A and 125 from B; and only 200 workers are needed. Who loses his job? Union $B$ wins the representation election and decides to endtail. Without a showing of bad faith conduct by Union B, the decision whereby 200 of B's employees and none of A's would get jobs would probably be upheld in court. ${ }^{102}$

Similarly, what would happen if Union $B$, three-quarters of whose members have worked longer than A's, decides to dovetail the seniority lists, thereby apportioning about 150 jobs to B's employees and 50 for A's? Absent a showing of bad faith conduct by the union, precedent would permit approval of the scheme.103

97 This, of course, would not be true if there were industry-wide seniority. The problem that this comment addresses itself to, however, would be obviated in such circumstances because there would be no need to integrate seniority lists.

98 Dooley v. Lehigh Valley R.R., 130 N.J. Eq. 75, 79, 21 A.2d 334, 338 (1941); N. ChaMmerLAin, LABOR 270 (1958).

99 N. CaAMberlain, LABor 269-73 (1958).

100 Ross, The Arbitration of Discharge Cases: What Happens After Reinstatement, Critical Issues in Labor Arbitration 29 (McKelvey ed. 1957).

101 This is similar to the situation in Fumphrey v. Moore, 375 U.S. 335 (1964), and Bieski v. Eastern Auto Forwarding Co., 231 F. Supp. 710 (D. Del. 1964), aff'd, 354 F.2d 414 (3d Cir. 1965).

102 See note 32 supra.

103 See note 31 supra. But see criticism of dovetailing in Kennedy, Merging Seniority Lists, Labor Arbitration and Industriad Change 55 (1963) (Proceedings of the Sixteenth Annual Meeting of the National Academy of Arbitrators). 
In both situations, Company B's employees are gaining a windfallgetting jobs which, but for the merger, belonged to Company A's employees. If Company B's employees had no seniority claims with respect to job opportunities when $A$ and $B$ were separate entities, why should they now that A and B are one? Surely, the seniority acquired by B's employees in respect to Company $B$ has no relevance to that acquired by A's employees in respect to Company A. To allow B's employees to claim jobs that once belonged to A's employees is to say, as did Justices Frankfurter and Jackson in their Trailmobile dissent, that the seniority rights of the minority group "were simply misappropriated to the benefit of the majority group."104

Further, if an employee of B is laid off, i.e., his seniority at B is insufficient for him to claim a job, he can make no claim on a job at Company A. Yet, in dovetailing a seniority list, the number of years he has worked for $B$ becomes very relevant in competing for a job that was created at $A$. The inconsistency reflects a misunderstanding of the nature of seniority rights-viewing seniority solely in terms of number of years rather than as job preference within a particular group. ${ }^{105}$

Do business mergers have any effect on this analysis of seniority? It seems clear that merger decisions are not made with reference to the seniority rights of either group of employees. ${ }^{106}$ As one arbitrator has put it: "Financial or tax advantages, or perhaps legal considerations may be weighed, but so far as the employees are concerned, it is sheer happenstance whether Company $A$ or Company $B$ survives in its original legal form."'107

\section{Structuring a Solution-The Contribution Formula}

To lump all the employees of both companies together and treat the merged company as a new entity for seniority purposes is to obscure the fact that the new whole is created by the contribution made by each of the two previously distinct companies. That the merger may generate

104 See note 42 supra.

105 "A seniority list is not literally or necessarily a list determined by time itself. It is rather a list which reflects the priority [of] job rights and opportunities of employees as among themselves which the employer agrees to respect." In re Pan American World Airways, 19 Lab. Arb. 14, 17 (1952) (Cole, Arbitrator).

108 "Employees, and the union which represents them, ordinarily do not take part in negotiations leading to a change in corporate ownership. The negotiations will ordinarily not concern the well-being of the employees, whose advantage or disadvantage, potentially great, will inevitably be incidental to the main considerations." John Wiley \& Sons v. Livingston, 376 U.S. 543, 549 (1964).

107 In re Pan American World Airways, Inc., 19 Lab. Arb. 14, 19 (1952) (Cole, Arbitrator). 
new jobs does not alter the fact that there is a contribution by each firm to total employment. ${ }^{108}$

This notion of relative contribution is crucial to a rational and equitable approach to merging seniority lists. By allocating jobs between the two groups of employees on the basis of the ratio of job opportunities provided by their former employers, ${ }^{109}$ neither group can gain a windfall at the expense of the other. Further, by inquiring not into the number of years worked but rather into a worker's priority of job preference within a particular group, this method is consistent with the theory of seniority discussed above. Commentators and arbitrators have seen the contribution formula as the soundest and most equitable way to eliminate political considerations. .110 $^{11}$

That the contribution formula is the most equitable and rational standard by which a court can judge the substantive faimess of a merger of seniority lists should not conceal the fact that other criteria may have some importance. Given two companies with labor forces having relatively equal distribution of years in service and no reduction in the number of employees to be used, dovetailing could roughly balance the interests of the two groups. ${ }^{111}$ Laying off married women during an economic decline so as to increase the likelihood that there will be a breadwinner in every family is a consideration, ${ }^{112}$ as is protecting union officials against dismissal ${ }^{113}$ and considering special job experience. ${ }^{114}$

In each instance the court must inquire into the reasonableness of the determination: whether the criteria used by the union to calculate

108 See Kahn, supra note 64 , at 372.

109 Within each group, the former seniority list will govern. In order to apportion the risk of layoff fairly between the two groups, the list must be integrated to reflect the ratio of job opportunities. Thus, if A contributes two-thirds of the jobs and $B$ onethird, every third name on the list should be an employee of $B$.

It has been suggested that once the ratio is calculated and those employees chosen, then the list should be integrated using length of service solely. See note 64 supra. The problem with this suggestion is that it puts the burden of the risk of layoff on the men with less seniority (in absolute terms), regardless of what their priority in job preference was before the merger.

110 See In re Sonotone Corp., 42 Lab. Arb. 359, 364 (1964) (Wolf, Arbitrator); In re Pan American World Airways Inc., 19 Lab. Arb. 14, 18 (1952) (Cole, Arbitrator); Kahn, supra note 64 at 371-74; Kennedy, supra note 103, at 17-22.

111 In re City of Green Bay, 44 Lab. Arb. 311 (1965) (Anderson, Arbitrator).

112 Fartley v. Brotherhood of R.R. \& S.S. Clerks, 283 Mich. 201, 277 N.W. 885 (1936). But see title VII of the Civil Rights Act of 1964, 42 U.S.C. $\$ 2000(e)-2(a)$. Section 703(a) provides: "It shall be an unlawful employment practice for an employer-(1) . . . to discharge any individual, or otherwise to discriminate against any individual with respect to his compensation, terms, conditions or privileges of employment because of such individual's ... sex . ...."

113 Aeronautical Lodge 727 v. Campbell, 337 U.S. 521 (1949).

114 Outland v. CAB, 284 F.2d 224, 228 (D.C. Cir. 1960). See Kennedy, supra note 103, at $32-34$. 
the contribution formula are reasonable in relation to that particular industry, ${ }^{115}$ and whether any deviations from this formula can be justified, such as those set out above.

Clearly, the basis for measuring the previous contribution of each employer varies with the occupation involved. ${ }^{116}$ In the railroad industry, for example, where the contribution formula is utilized, different criteria are used depending on the group affected.117 The Order of Railway Conductors and the Brotherhood of Locomotive Engineers both prescribe that the runs in a merged operation will be manned in proportion to the mileage run on the territory of each of the original roads. 118 The Brotherhood of Railroad Trainmen relies upon "engine hours worked by the respective lines" in the respective yards when these are to be merged in connection with the services of yardmen. ${ }^{119}$

In considering the shape of litigation, it should be the plaintiff's burden to prove the unreasonableness of the criteria selected in constructing the contribution formula. ${ }^{120}$ As to deviations from the formula itself, the burden should fall to the union to show the reasonableness of any deviations. ${ }^{121}$ Whatever the burdens, the task of the court is central in judging the scope of reasonableness accorded to the union. The contribution formula itself does not eliminate political considerations, for the union will, to some extent, be allowed to choose the criteria and the weight accorded to each. At least, the fear that it may have to go into court and establish the reasonableness of its determination, whereas previously it didn't unless bad faith conduct was present, will have a dampening effect on the union and eliminate blatantly discriminatory solutions such as were reached in Trailmobile and Wheland. In addition, if it is assumed that the union leadership wants to live up to the duty of fair representation and only creates discriminatory solutions in response to the majority, the presence of the contribution formula may have an educative effect. It enables the union

115 The court must ascertain whether the union, in using the criteria, also calculated the formula correctly. In addition to this requirement of reasonableness, the good faith requirement is retained. Thus a formula would be invalid if, in spite of the reasonableness of the criteria used, the criteria selected were chosen so as to discriminate against one group, for example, all Negroes involved.

116 Kahn, supra note 64 , at 371.

117 Id. at $371-73$.

118 Id. at 371.

$119 \mathrm{Id}$.

120 In setting up a standard, one has to balance between the fear of a great many harassment suits and setting up a standard so broad as to make the plaintiff's case as difficult as it is under the present bad faith test. This balancing is achieved by having plaintiff prove the unreasonableness of the criteria used, but by having the union show the reasonableness of any deviation from the contribution formula itself.

121 See note 120 supra. 
leadership to justify its actions to its members on the grounds that it must comply with its legal duty of fair representation.

The courts have a crucial role in putting meaning into a flexible standard of reasonableness; too lax a standard may leave the individual in a position where he is not much better off than he is today. The function of the court, then, is to create law, finding guides in the industrial world and the moral precepts of the community-a task, as one observer sees it, "no more nor less difficult than in situations where the common law judge is required to particularize some general rule of reasonableness." 122

As can readily be surmised, the difficulty with the formula lies in calculating the contribution of the respective parties. ${ }^{123}$ The difficulty varies with the nature of the merger. ${ }^{124}$ If $A$ produces widgets and $B$ produces hula hoops and now $\mathrm{AB}$ produces transistor radios, the problems involved in calculating the individual firm's contribution are substantial. The more homogenous the merging firms are, however, the easier the calculation. Given the proliferation of mergers in the transportation industry, ${ }^{125}$ for example, and the seniority disputes generated by them, ${ }^{126}$ the heterogeneity problem in calculating the contribution formula is not as great as it might appear.

\section{CoNGLUSION}

Seniority defines the order of claims to a job opportunity within a particular work unit. When seniority lists are merged, the nature of seniority rights is often obscured, and sheer power usually prevails in reaching a method of integration.

By turning to the contribution formula, courts will be better equipped to judge the substantive fairness of a union's solution rather than limiting their inquiry to the union's conduct in reaching the

122 Cox, Rights Under a Labor Agreement, 69 HARv. L. REv. 601, 632 (1956).

123 Two other problems are present: when to integrate the list and what to do if additional jobs are created by the merger. As to the first, integration should take place whenever the employer requests, and the ratio of job opportunities should be calculated at that time. If the employer moves from his position of neutrality (see note 11 supra) and tries to time his request for integration so as to favor one union or the other, a section $8(a)(1)$ or $8(a)(3)$ violation could be found. As to jobs that neither firm contributed but were created because of the merger, they should be apportioned between the two work forces on a 50-50 basis.

124 Kennedy, supra note 103, at 20-22.

125 Mater \& Mangum, The Integration of Seniority Lists in Transportation Mergers, I6 IND. \& LAB. REL. REv. 343, 344 (1963).

126 E.g., Humphrey v. Moore, 375 U.S. 335 (1964); Fyland v. United Airlines, 254 F. Supp. 367 (N.D. Ill. 1966); Fischer v. Guaranteed Concrete Co., 151 N.W.2d 266 (Minn. 1967). 
solution. The formula enables the courts and the NLRB ${ }^{127}$ to go beyond what is, to the employees involved, the fringe issue of the union's good or bad faith, and take up the central issue of who gets the jobs. Of equal importance, the contribution formula is consistent with the economic rationale behind seniority and shifts the focus away from political considerations.

Appreciation of the inequities of judicial non-intervention in the area of merging seniority lists and the availability of a practical, economically-based formula should induce courts to put new meaning into the duty of fair representation. The element of reasonableness permits flexibility for the courts, so that they can police solutions without demanding an abdication by the unions of their decisionmaking prerogatives. The contribution formula is sufficiently precise to fully involve the courts in the problem and effectively discourage the self-serving solutions of the majority.

127 All that has been said about the courts in this comment applies generally also to the NLRB. The Board, however, has pursued a more vigorous policy of intervention than have the courts and has been far more cognizant of the underlying tensions. See The Trailer Co. of America, 51 N.L.R.B. 1106, 1114 (1943); The Wheland Co., 120 N.L.R.B. 814 (1958). In all probability, a plaintiff would have an easier time proving a violation of the duty of fair representation before the Board than in court. 